\title{
Economic empowerment of rural women through SHGs in Jajpur district of Odisha
}

DHARITRI PATRA AND GAYATRI BISWAL

Received: 01.05.2017; Revised: 04.10.2017; Accepted: 18.10.2017

See end of the paper for authors' affiliations GAYATRI BISWAL

Department of Home Science, Rama Devi Women's University, BHUBANESWAR (ODISHA) INDIA
ABSTRACT : Rural development and reduction of poverty are the two important objectives of our nation. Self help groups (SHGs) have been proved to be an effective means to achieve these two objectives. The SHGs in Odisha have been in the services of rural women for quite a long time with successful achievement. The importance of SHGs in elimination of poverty has been greatly realized. A study conducted on "Economic Empowerment of rural women through SHGs in Jajpur district of Odisha" reveals that SHGs in the state is at increasing trend fulfilling the requirements of their members. Many researchers are in opinion that emerging SHGs are the right channel to reach and empower rural women.

KEY WORDS: SHGs, Rural development, Poverty, Empowerment, Rural women, Economic

- HOW TO CITE THIS PAPER : Patra, Dharitri and Biswal, Gayatri (2017). Economic empowerment of rural women through SHGs in Jajpur district of Odisha. Asian J. Home Sci., 12 (2) : 421-426, DOI: 10.15740/HAS/AJHS/12.2/421-426. 